\title{
NARRATIONS OF MENTAL HEALTH OF YOUNG WOMEN NOT IN EDUCATION, EMPLOYMENT OR TRAINING (NEET) FROM MEXICO AND SPAIN
}

\section{NARRACIONES DE LA SALUD MENTAL DE MUJERES JÓVENES QUE NO ESTUDIAN NI TRABAJAN (NINIS) DE MÉXICO Y ESPAÑA}

Raúl Alejandro Gutiérrez García ${ }^{1}$, María de la Villa Moral Jiménez ${ }^{2}$, Kalina Isela Martínez Martínez ${ }^{3}$ y Rogaciano González González

\author{
'Universidad De LaSalle Bajío, campus Salamanca \\ 2 Oviedo University, Spain
}

${ }^{3}$ Autonomous University of Aguascalientes, México

\section{Abstract}

The purpose is to understand mental health in young women not in education, employment or training (NEET) through the meanings attributed to life experience. From a larger study that included women, fifteen early adult women participated in this study using an intensive intentional sampling strategy. We carefully selected only a few cases, seeking to characterize the object of study and to obtain in depth information based on the participants' subjective reality; they were females from Oviedo, Spain and Aguascalientes, Mexico. We found in young NEET women different emotional expressions of mental health related to the feelings of not being in the situation of not working or studying, such as sadness, loneliness, anxiety, stress, fear, frustration, and discomfort. These women experienced loneliness when felt they did not have friends, since they were isolated not going to school or work. These life stories allowed understanding, from the feminine subjective perspective, the emotional experience of NEET, which, according to the meanings they mentioned, are specific forms of distress and depression with repercussions for their mental health. These results demonstrate the relevance of new public policies on mental health, education and work to attend to the needs of this population.

Keywords: early adults, women, mental health, Mexico-Spain

\section{Resumen}

Este artículo tiene como objetivo analizar la salud mental en las mujeres jóvenes que no estudian ni trabajan a través de los significados atribuidos a la experiencia de la vida. Fueron 15 mujeres jóvenes que participaron en el estudio que participaron en un estudio más amplío solo se eligieron a las mujeres, que fueron seleccionadas mediante una estrategia intensiva de muestreo intencional; fueron mujeres jóvenes de Oviedo, España y Aguascalientes, México. Los resultados sobre la salud mental, se encontró que en las jóvenes hay diferentes expresiones emocionales relacionados con el malestar por no estar trabajando o estudiando, tales como la tristeza, la soledad, la ansiedad, el estrés, el miedo, la frustración y malestar. Estas mujeres experimentan la soledad cuando ven que ya no tienen los mismos amigos por no ir a la escuela o al trabajo. Estas historias permitieron entender cómo desde la perspectiva subjetiva femenina, la importancia que han experimentado el ser "NiNi" que, de acuerdo con los significados que les dieron, son formas específicas de la ansiedad y la depresión con repercusiones en su salud mental. Los resultados sugieren crear nuevas políticas públicas de atención en salud mental, educación y trabajo.

Palabras clave: adultos tempranos, mujeres, salud mental, México-España. 
Mental disorders constitute a public health problem with a major impact in terms of dependence, disability, economic costs and health (WHO, 2007). In Mexico, the $28.67 \%$ of adults had experienced the onset of a psychiatric disorder (Medina-Mora et al., 2003). A diagnostic character study is the ESEMeD (European Study of the Epidemiology of Mental Disorders), which estimated that $15.7 \%$ of men and $22.9 \%$ of women in Spain had a mental disorder at some point during their life and 5.2 and $11.4 \%$, respectively in the last 12 months (Haro et al., 2006). In Mexico, depression as symptom or as a mental disorder is more prevalent in adolescents (Benjet et al., 2009). Major depression ranks fourth among the five leading causes of diability adjusted life years lost in Mexican women (Lozano et al., 2013). Mental health is affected not only by internal factors of individuals or social groups but also it has an impact on itself. Young individuals are especially vulnerable to challenges in their social context, since they count on limited social resources or power to get by; besides, the human development process brings a diversity of options for youth to select, but very few of those options are actually at their reach. Counting on limited choices is a reason why the young are easily influenced. A social group that promotes mental health is one in which security and opportunities for development are available, so that the young will develop a positive concept of self and will deal with others in an equality of circumstances (Breslau, Lane, Sampson \& Kessler, 2008; Rodríguez, Kohn \& Aguilar, 2009).

At an early age, disorders impair the educational and job opportunities of the young, also their choices when selecting partners and their general life, undesired pregnancies are another source of pressure (Bernfort, Nordfeldt \& Persson, 2008). Individuals under 15 years of age represent up to $30 \%$ of the population of Latin America and the Caribbean, and more than $40 \%$ of the populations of some countries in the region of Guatemala and Belize as two countries in Europe and America (Bureau, 2007); 19\% of the population in the region is between 15 to 24 years of age (United Nations World Youth Report [UNWYR], 2014). Even so, the lack of epidemiological data that record the needs of the population in the areas, but it is necessary to know that perceived young women who possibly does not have social security.
It is through the scientific advances of the last decades that causes of mental disorders are better understood nowadays. New types of interventions of proven efficacy have been implemented to prevent and treat these health problems; still, most women do not have access to those. The first results of mental health surveys conducted in several Latin American countries show that $80 \%$ of women with mental health problems don't have access to health services (Duarte et al. 2003) and there is also the fact that young women are the individuals that have the most probabilities of developing mental health problems (Benjet et al, 2009). Therefore, estimates of prevalence of these problems go up as people grow older (when adolescents and young individuals are contemplated), and some longer reference periods are contemplated. Prevalence of any disorder varies between $12.7 \%$ and $15 \%$, while prevalence in the last 12 months has varied between $8.5 \%$ for serious disorders and 39.5\% for any disorder (Rodríguez et al., 2009)

In Latin America and the Caribbean, 29\% of women between 20 to 24 years of age were married before turning 18. In Mexico, this percentage reaches up to 33\% (UNICEF, 2005). Women have a higher prevalence of any disorder compared with men when asked about the last 12 months (Medina-Mora, et al., 2003). In Spain, the most important determinant factors for mental health of young people and women are: poverty, low education/literacy, state of economic deprivation, a difficult childhood, unemployment, drug abuse, alcohol and other substances harmful to health (Gil, et al. 2012). These young women have lower educational level and more children. They married older men, and have greater probability of becoming victims of domestic violence. Adolescent pregnancy and early age of maternity are linked to mental health problems both in the mother and in their offspring (Barros, 2010).

Young individuals are the ones in highest danger of suffering domestic and street violence, physical, sexual and psychological violence in the home being the most common forms of mistreatment they are exposed to; also witnessing violence. Outside their homes, the most common forms are work and school violence. In their jobs, women are subjected to more restrictions than men are, and in educational institutions, the careers that offer greater chances of social mobility are only accessible to 
men and sexual harassment at school and work (Rodríguez et al, 2009).

One study found that young males feel under pressure because they cannot express themselves freely, since society does not favor their showing weakness (crying in public), while young women that they have fewer chances of excelling professionally, but what makes them the most proud is their ability to give life, though as time passes, they keep putting off child rearing to a later age (Hernández, Coronado, Araújo \& Cerezo, 2008). This might be explained by the fact that a difficult economic situation usually forces women to have a job, because households with only one breadwinner cannot cover the necessities of a family. Some Sociology studies discuss the question of gender, they talk about gender oppression (Abramo, 2006; Ruiz, 1998), about the need to clarify the inequality that exists between genders and about a supposed commitment between supporters of both currents to help transform social reality through academic thinking, ethical and political work. Reflection generated through these efforts might contribute to better assert that there is actually no difference between NEETs of either gender and to reanalyze topics in this area from angles that have not been taken into account until now. Non-paid work activity and the exclusive development of domestic tasks correlates with worse mental health index (Confederación Salud Mental España, 2015)

Based on these conclusions, it can be said that more studies on different aspects of young people must be conducted, since they are a vulnerable sector of the population. It is necessary to do more and different research on the young who cannot be found at school or in the workplace, especially young women who are at greater risk for social exclusion. Another sector of the population in this case is individuals with an illegal migratory status, with a low educational level and those who live far from cities or job sources.

Young contemporary postindustrial societies go through a period of transition to increasingly postponed adult life, increasing the gap between the psychobiological acquisition of maturity and psycho-social level and the full implementation of the processes of family emancipation and social and professional integration (Moral, 2007). They have been classified as social teenagers, despite being chronological adults. This period of psychosocial moratorium imposed by the socioeconomic conditions of post-industrialism in technologically advanced societies has extended, which affects significantly the construction process of their social identities, interacting as flexible actors such constitutive processes.

Regarding youth, education and work in Mexico or Spain, they are complex issues to address, in part because today youth live a transitional socio-educational process, affected by political, social and economic factors and facing the cyclical characteristics of the market. When reflecting upon young NEET women, an age limit needs to be agreed upon for the purposes of different studies (behaviors, interpersonal relationships and expected activities among other indicators); also juvenile practices that can be pointers of age and sex, just to mention some aspects. In this order of ideas, investigations carried out with young women populations show the establishment of a complex system of categories that includes at least certain given components like: opposition against a group that is judged as very homogeneous, (students vs. workers). According to the facts presented in the analysis previously presented, the purpose of this paper is: to understand the life experiences of those Not in Education, Employment, or Training (NEET) and how that affected emotions, ideals and way of life comprising mental health.

\section{METHOD}

\section{Design}

In this investigation, the comprehensive interpretive approach is utilized as its strategic methodology in order to have access to the experiences of young NEET women, because when individuals share their experiences, they have a chance to listen to new ideas and ask questions, and this way their depth of understanding broadens. At the same time, the form in which these young women voice their experience emanating from their subjective interpretation of them will provide new elements to study the social construction. Right from a comprehensiveinterpretative perspective (Ulin, Robinson \& Tolley, 2006) and a constructivist conceptual framework, using a qualitative paradigm, the representation of individuals that at present have an experience of not studying or 
working were released from their subjectiveness (Guba \& Lincoln, 1994).

\section{Participants}

The participants were fifteen NEET women living in the cities of Aguascalientes, Mexico and Oviedo, Spain. To select informants, a theoretical sampling approach (Glasser \& Strauss, 1967) was employed. Through this technique, cases that can characterize the phenomenon under study can be carefully selected so that they will supply objective and significant information (Patton, 1990).

\section{Procedure}

The design and implementation of the interviews were conducted in two parts: 1) In Mexico, exploratory interviews were conducted with young people, topics of interest to learn about their experience, later studies were preliminary to define the inclusion criteria and the guide questions, finally interviews were conducted with 8 youth of this city. 2) In Spain, it was a re-structured guide of questions to fit the uses and idioms of Castilian Spanish. They were exploratory interviews to understand the context of these youth. The Coordination of youth programs in Asturias was contacted and support was requested to identify potential candidates. Once the contact was made, they were informed on the objectives of the interview and finally 7 interviews were conducted. In total, there were 32 interviews, but only women were selected for this investigation.

The inclusion criteria were young women from Aguascalientes and Oviedo:

- 17 to 24 years of age.

- At least 6 months of not studying or working.

- Not enrolled in any school level.

- Not working within the "formal" market.

- Voluntarily agree to participate in the study.

What is most important is not the number of individuals interviewed, but how much the information obtained may portray the results pursued. Sample decisions that were made during the experimental phase of the work were made based on a selection and comparison of participants in order to prove the theoretical implications posed (Goetz \& Le Compte, 1998).

Participants were contacted through "support networks" asking people who knew women who were not enrolled in any educational institution and who were not working at the moment. Once all personal data had been gathered, possible participants were contacted by telephone and were asked for an interview. They were given an idea of the type of study and the objectives of the investigation; they were also asked the length of time they had been in that situation in order to select candidates that fit all the requirements of the study.

An appointment was scheduled and informed consent was obtained in person. It was central to explain to participants that if at any moment they decided they did not want to continue participating, they were free to do so. From the first contact, the objective of the investigation was carefully explained to them. To provide ideal conditions for participants, interviews were carried out in their houses, though in nine of the cases, a space was improvised for the purpose of comfort and privacy, at the Autonomous University of Aguascalientes and the Youth Information Office from Oviedo.

The way of approaching participants was through conducting interviews in order to obtain all information needed. This method is one of the ones most utilized in social investigation (Kvale, 1996), an interview is also considered the ideal tool to obtain and recreate the significant experience of neither studying nor working. Selection of this method responds to the possibility of establishing a personal interaction with participants towards a comprehension of perspective informants have about their live, experiences and situations the way they voice them using their own words (Taylor \& Bogdan, 1992).

Transcribed interviews were carefully read and re studied in order to identify the ideal elements of analysis that met the objective of the investigation. In order to identify, order and codify the information obtained from the interviews, data was processed using the MAXQDA software.

Subsequently, a set of categories was devised to classify the information obtained from the different topics dealt with throughout the conversations. These categories were decided based on the purposes that had 
been proposed in the interview guides, and are grouped using a technique called categorization of meanings. The focused interview guide was designed to explore categories of: Identity, self-perception, life goals and mental health. To meet the objective of this work, selfperception of mental health was analyzed. To make this task easier, a thematic index was written which contains the main topics and the order in which they were analyzed. After this, the steps of "condensation" and "interpretation" and category analysis of the information were carried out (Kvale, 1996). The material was codified and then all categories obtained were compared for each of the participants. For non-biased information a triangulation was blind, with social psychology experts from Spain and Mexico.

In order to do research which complies to ethical requirements (Neuman, 1997), each young person explained the reasons for the research also verbal and written informed consent was agreed in the which they reveiled the purpose of the study, the procedure for making the interview, voluntary participation and confidentiality. Other ethical considerations were returning the information to participants and in two cases providing options of psychological support given the interest and experiences of the young people in question.

\section{RESULTS}

With respect to areas in which the study was conducted, it is important to note that populations are characterized by a higher rate of the average of each country of young people. Table 1 shows some demographic characteristics of the participants.

The table shows that of the seven young people from Spain aged 18 to 23 and the eight from Mexico aged 18 to 24 years old, those from Spain overall had a higher educational level.

\section{Mental health: "it depresses me..."}

In this study, mental health is given a relevant place, because one of its main goals was to understand, right from the viewpoint of social constructivism, if certain types of macro and microsocial discourses linked with the experience of NEET young women can be connected with different emotional characteristics of unhappiness, frustration, sadness, or anger that are difficult to face due to their situation. If one considers theoretical evidence, the fact that they suffer from different given disorders can be explained by the fact that they suffered different situations through their younger years. Literature in the area points out that the situation of these young women are going through involves, besides what had been mentioned in accounts of alcohol or drug abuse, a risk of suicide during their productive years, most especially when they are unemployed. It was also found that the experience of having suffered sexual abuse was a factor that led two of the participants to quit school.

Table 1. Sociodemographic characteristics of NEET young women

\begin{tabular}{lll}
\hline Age & Level Education & Birthplace \\
\hline 22 & Secondary & Mexico \\
19 & High School & Mexico \\
18 & High School & Mexico \\
19 & High School & Mexico \\
24 & College & Mexico \\
18 & High School & Mexico \\
20 & Secondary & Mexico \\
19 & Secondary & Mexico \\
21 & High School & Spain \\
20 & High School & Spain \\
19 & High School & Spain \\
18 & High School & Spain \\
22 & College & Spain \\
19 & High School & Spain \\
23 & College & Spain \\
\hline
\end{tabular}

On the issue of mental health, participants showed different affective reactions to the distress of not studying or working; they reported having feelings of sadness, loneliness, anxiety, stress, fear, frustration and remorse among others. It is important to mention that these reactions, both in male and female participants are linked to how anguishing it is to not being able to find a job and in other cases to not being studying because they threatened their family, social and interpersonal equilibrium.

The following topic is manifestations of distress and how participants expressed these feelings towards their perceived disappointments and losses. One of the participants experienced loss with the death of a beloved one and after not having passed entrance exams at an educational institution. In her words, Josefina says "[...] I didn't pass the exams... I feel very sad ... very sad because I didn't pass the entrance exams in the career I wanted, what 
do I do now, wait? ... Yes, I feel very lonely, locked up in my world... I tend to get depressed ...» Paula explains «[...] When my grandmother died, my life changed, I was always sad, I didn't want to live, the most important person to me had gone ... I was left alone...» Melisa also has a story "[...] An acquaintance who didn't study or work committed suicide, the difference is he did it in the middle of a Street when they were having a celebration in his neighborhood, which means that there were lots of people. They had some Fireworks and he just came out of nowhere and shot himself; then he survived, but he at least attempted suicide because he said he was already bored, and there were lots of us who knew him...» Another of those accounts was offered by Rosy "[...] I feel bad because when I had finally passed entrance exams at the university I could not enroll because I didn't have money and to make things worse, I had been fired from my job ... Before meeting my boyfriend I didn't have anybody, I felt really bad..."

Feelings that can be identified in this narrative go from sadness to loneliness. Sadness might seem to be an emotion that it is not hard to experiment then it is not hard to put in words, but it might seem that this "sad sadness" comes as a consequence of loneliness; thus, reflecting upon a possible connection between sadness and loneliness makes young individuals not feel backed up during the lonely times they are facing. Said in few words, right from a social constructivist point of view, what we consider knowledge of the world is determined by the culture, the history or the social context. When not being inserted in the social spaces considered appropriate, the young feel sad and lonely.

On the one hand, frustration was a common feeling with those informants who could not find a job. This comes as a result of the few job opportunities available to them. Amanda expresses her frustration in this way: Amanda "[...I sent my résumé and I didn't get hired... this is disappointing, and I feel bad, because I'm doing nothing...» Rosario says "[...] I feel bad because I don't get a job... even if I go with Friends, there are no jobs and, what can I do?... I go back home...» Maria puts it this way "[...] If I don't have a job, I have no choice but to stay home... and I do feel bad when I know that others have a job...» Xochitl explains "[...] there is no job, and thus I have to go to juvenile hall, but I feel bad, because they keep telling me to wait... there's nothing...» Regarding the way in which these young informants face this sadness and frustration, they say they do this by talking to their boyfriends or partners and with their parents, since they make them feel understood, but there are times when they do not look for company, they just isolate themselves or soothe themselves with the use of alcohol or drugs, which is the case of Sara and Xochitl.

The fact that subjects are unwell because they can not find a job or study a career was manifested during all interviews at certain given moments in which their faces showed the pain and the sorrow they feel because they cannot do what they wish they could do; for example, in the case of Rosario and Josefina. These manifestations are connected to feelings of vulnerability that they have constantly showed in different scenarios of their life or during the same interview. Claudia expressed the following "[...] at least I need to finish junior high in an open studying system, because if I don't fill this requirement I won't even get hired ...» Guadalupe stated «[...] In order to study, first I've got to have a job. If I don't, I am going to be out of the university like it happened to me years ago.

Another way of expressing their frustration was through criticism against the government and the educational system, since they say their state of not working or studying is not the situation they want, but either there are not enough universities or there are no jobs. A participant, May says «[...] I keep on applying for jobs... But there aren't any... This is also fault of the local government...» Josefina states "[...] I can't study at a private university, because I don't have any money ... I must wait...»

All these faces reflect the anxiety they feel due to the effort of trying to find a job and not being able to as well trying to enter a university and being rejected because of the common supposition that only the "best" ones got chosen, which has to do with the experiences of their families who say "the situation gets harder and harder as time goes by". It would be interesting to investigate if these feelings are commonly manifested by young men who neither work nor study.

\section{DISCUSSION AND CONCLUSION}

We discuss some findings in light of the conceptual framework, social constructionism, which supported the study, trying to articulate the different elements that contribute to the formation of the meanings attributed to the experiences of young NEET women. Among the main macrosocial characteristics, the discourse of incidental 
participants can be highlighted, since it states that NEET women are observers and survivors of public policies that are not realistically oriented. The young have been labeled, but they have not been given the attention that is needed in employment and academic areas. What choices are there then for them?

In these areas, frustration is being generated in the life of each one of the subjects interviewed. It was found that the satisfaction of finding a job is one of the main reasons that motivate these individuals to study or not. These situations have led the young to press for social change, as has been the case of the group "yosoy132" in Mexico; no doubt the lack of effectiveness of the national governments was a detonating factor that has made people organize themselves in this and other groups, the problem is that their sense of direction and policies have been built unrealistically due to the fact that they were not well informed on what really is going on; then these ambiguities are promoted by the mass media, and politicians made it clear that there is a sector of the population whose reality they don't much understand, thus all these discourses are knitted on the fringes of society and are totally biased.

Several important elements can be distinguished that interlace with relation to identity-self-image-concept of self: the right category for the "young" in this sense was recognized, as well as the necessity to find out different aspects that have to do with it. In this category, it is highlighted that young women use different categories to think of themselves according to the situations they live in, but another element is the way they see themselves. Their narratives do not reflect an auto appreciation, a self recognition of a group socially labeled, and if it is possible to see them as a group, it would be the young population with different manifestations, ways of living and self perceptions.

Among the common experiences that these young individuals share, there are mental health problems that manifest themselves as sadness, frustration and substance use; there are goals that these individuals are trying to attain, which shows that they still have a sense of identity. Mental health is thought as important, because it is relevant to analyze the costs that for the young are involved in the development of a self-identity, since being unemployed or uneducated both result in contradictory experiences that have a very negative impact upon their mental health; these situations become more dramatic if individuals do not have a way of supporting themselves, since in those cases their autonomy might be threatened, then their inability to fulfill social expectations deepens, causing them even more damage. Luckily, this status is transitory since most of the informants, by the time of their interviews.

This investigation found that in some cases, the frustration of not finding a job was seen among the adversities that haunted the family, together with physical health issues, sexual abuse in adolescence, mourning due to the loss of loved ones and drug abuse issues. These traumatic events, which brought about the exercising of power, control and domination on the part of parents or authority figures, threatened the equilibrium of these young individuals, had an impact in their identity and triggered important psychological effects, mainly while establishing affective bonds, since at different moments, they tend to feel lonely.

One of the ways these young women found as they were trying to assert themselves as "women" was to start an active sexual life with their corresponding partners. Finkelhor y Browne (1985) have mentioned that when adolescents are subjected to abuse, they might present certain rejection against sexuality, but in these two cases, these girls developed a sex addiction and did not take long to rebuild their identities. Still, it is important to mention that these practices also brought about pressure on the part of their partners.

As for the characteristics and the context in which these young women live, they are middle class women, and the heads of their families are working people. This family networks in this sense, protect them, which hinder their need for independence and thus their ambition to fulfill their goals, but on the other hand, provide affection, which is important in the construction of their identity; besides the fact that their support strengthens their abilities to connect with peers out of the family circle. Many times, the fact that both parents work outside of the home all day works as pressure, since they expect that their children will have a higher level of education, because this in turn will mean an expectation for a better standard of life.

These young women also tend to try to find jobs that have to do with what they have studied, though these opportunities many times do not come easy. Some of the 
careers that they commonly study are administration or social sciences. Still, it can be seen that all young individuals think that achieving professional development is an expectation that leads them to try to build networks that will enable them to achieve a more advantageous insertion into the job market. On the other hand, the loss of school friends and all the trouble with finding a job, a tendency to find refuge in drugs, these were all experiences that some of the informants reported having gone through, and which produce frustration in two important structures, the affective and the social ones.

All interviewed informants were people who did not want to stay out of a job or out of school, because they are in conditions to work and because they actually never thought of quitting their goals, though those who have found a job have signed temporary contracts, and for this reason they keep trying to find a job and, when they go back at it, they are going to be faced with the same obstacles as before (first job); but also there are some who only seek intermittently, because of lack of faith or because they are asked to contribute with the needs of their families (particularly homemaking and attending family members in different situations). In this sense, job seeking and the returning to studies depend on different factors, most commonly those alternative activities that they are doing when they do not have a job like studying languages, doing volunteering or family support tasks. This way, the routes back to school or employment of these individuals are longer and more diverse. Such trajectories are not linear and very often, frustrated returns, lack of hope and trouble are seen.

It was found that the dynamics of stigmatization that these women have to put up with are characterized by offensive treatment, a situation that was created by some of them, and which made their situation even more complex, since, besides being excluded from school and work, these offenses give them a sense of guilt and makes them feel manipulated to fulfill an imaginary official role. Unfortunately, stigmatization is commonly exacerbated and ventilated. This increments the difficulty of inserting themselves into institutions to secure their social participation, which frequently causes these women to isolate themselves and, in some cases, live in an absolute silence, and this is why being interviewed represents an important cathartic space, since they do not usually get opportunities to voice what they really think.
Powerlessness can be characterized in these young women in their feelings of fear and anxiety when looking for jobs. As a matter of fact, many of them sought help of witches to "cure" the spell which stopped them from finding jobs or affected their physical health. These problems often stretch up to the adult age. During the interviews carried out, it was possible to see that this situation of not studying or working is a harmful one, because of the effects it has on the mental health of the individual.

Finally, we emphasize that this qualitative article focused on the reality reported in young NEET women in Mexico and Spain through the analysis categories linked to mental health. These results could have been complemented by cutting edge quantitative studies to provide other dimensions of the phenomenon. Also, we must emphasize that we provide an analysis from individuals' perspectives and is only a discourse of NEET women living under various circumstances.

\section{Acknowledgments}

This project was realized with the support of the Autonomous University of Aguascalientes, the University of Oviedo, the Asturian Youth Institute and first author financing granted by the National Council of Science and Technology (CoNaCyT) as a Ph.D student.

\section{REFERENCES}

Abramo, L. (2006). Trabajo decente y equidad de género en América Latina. Santiago de Chile: Organización Internacional del Trabajo

Ayuso-Mateos, J.L., Vázquez-Barquero, J.L., Dowrick, C., Lehtinen, V. Dalgard, O.S., Casey, P., et al. (2001). Depressive disorders in Europe: Prevalence figures from the ODIN study. The British Journal of Psychiatry, 179, 308-316.

Benjet, C., Borges, G., Méndez, E., Albor, Y., Casanova, L., Orozco, R., Curiel, T., Fleiz, C. \& Medina-Mora, M. (2016). Eight-year incidence of psychiatric disorders and service use from adolescence to early adulthood: longitudinal follow-up of the Mexican Adolescent Mental Health Survey. European Child and Adolescent Psychiatry, 25, 163-73 doi: 10.1007/s00787-015-0721-5

Benjet, C., Hernández-Montoya, D., Borges, G., et al. (2012). Youth who neither study nor work: Mental health, education and employment. Salud Publica Mexico, 54,410-417.

Benjet. C., Borges, G., Medina-Mora, M., Zambrano, J. \& Aguilar-Gaxiola, S. (2009). Youth Mental Health in a Populous City of the Developing World: Results from the Mexican Adolescent Mental Health Survey. 
Journal of Child Psychology and Psychiatry, 50, 386-395. doi: 10.1111/j.1469-7610.2008.01962.x.

Bernfort, L, Nordfeldt, S., \& Persson J. (2008) ADHD from a socio-economic perspective Acta Pediatrica; 97(2):239-45.

Bresalu J, Lane M, Sampson N, Kessler RC. (2008). Mental disorders and subsequent educational attainment in a US national sample. L Psychiatr Res 2008;42(9):708-16.

Confederación Salud Mental España (2015). La salud mental en el trabajo. España: Editor.

Duarte, C., Hoven, C., Berganza, C., Bordin, I., Bird, H., Miranda, C. (2013) Child mental health in Latin America: Present and future. Epidemiologic research, 33(3):203-222.

Finkelhor, D. \& Browne, A. (1985). The traumatic impact of child abuse: A conceptualization. American Journal of Orthopsychiatry, 55(4), 530541

Gil, M., Roca, M., Basu, M. Mckee, M. \& Stuckler D. (2012) The mental health risks of economic crisis in Spain: evidence from primary care centres, 2006 and 2010 Eur. Journal of Public Health;23(1):103-1188. doi: 10.1093/eurpub/cks035.

Gili, M., Ferrer, V., Roca, M., y Bernardo, M. (2000). Trastornos psiquiátricos y comorbilidad médica en un estudio epidemiológico comunitario. Psicothema, 12, 131-135.

Glaser, B.G. \& Strauss, A. (1967). The Discovery of Grounded Theory: Stretegies for Qualitative Research. Chicago: Aldine.

Goetz, J. y Le Compte. (1988). Etnografía y diseño cualitativo en investigación educativa. Madrid: Morata.

Guba, E. \& Lincoln, Y. (1994). Competing paradigms in qualitative research. En: N.K. Denzin \& Y.S. Lincoln (Comp.), Handbook of qualitative research. London: Sage Publications.

Haro, J.M., Palacin, C., Vilagut, G., Martínez, M., Bernal, M., Luque, I., et al. (2006). [Prevalence of mental disorders and associated factors: Results from the ESEMeD-Spain study]. Medicina Clínica, 126, 445451.

Hernández, M., Coronado, O., Araújo, V. y Cerezo, S. (2008). Desempeño académico de universitarios en relación con la ansiedad escolar. Acta Colombiana en Psicología 11, (01) pp. 13-23.

Kvale, S. (1996). InterWiews: An introduction to qualitative research interwiewing. London, England: Sage Publications.

Lozano R, Gómez-Dantés H, Garrido-Latorre F, Jiménez-Corona A, Campuzano-Rincón JC, Franco-Marina F, Medina-Mora ME, Borges G, Nagavi M, Wang H, Vos T, López AD, Murray CJL. (2013) La carga de enfermedad, lesiones, factores de riesgo y desafíos para el sistema de salud en México. Salud Publica Mexico, 55:580-594.

Medina-Mora ME., Borges, G., Muñoz, C., Benjet, C., Jaimes, J., Bautista C. et al. (2003) Prevalencia de trastornos mentales y uso de servicios: resultados de la Encuesta Nacional de Epidemiología Psiquiátrica en México. Salud Mental;26: 1-16.
Moral, M. (2007). Preparación para el trabajo de los jóvenes contemporáneos en una sociedad postindustrial: trabajo, educación y globalización, Estudios sobre Educación, 13, 71-194.

Neuman, W. (1997). Social research methods. Qualitative and Quantitative. Boston: Alyn y Bacon.

Patton, M. (1990). Qualitive evaluation and research methods. Newbury Park, CA: Sage.

Population Reference Bureau. (2007) World population data sheet. Washington, DC: World Popu- lation Bureau; 2007.

Ramrakha S, Bell ML, Paul C, Dickson N, Mof- fitt TE, Caspi A. Childhood behavior problems linked to sexual risk taking in young adulthood: a birth cohort study. J AM Acad Child Adolesc Psychiatry 2007;46(10):1272-1279.

Rodríguez, J., Kohn, R., \& Aguilar,S (2009). Epidemiología de los trastornos mentales en América Latina y el Caribe. Revista Facultad Nacional de Salud Pública, 28(2), 183-184. Retrieved August 25, 2016, from http://www.scielo.org.co/scielo.php?script=sci_arttext\&pid=S0120386X2010000200011\&lng=en\&t|ng=es.

Ruiz, J. (1998). La juventud liberta. Género y estilos de vida de la juventud urbana española. Bilbao: Fundación BBV.

Taylor, J. y Bogdan, R. (1992). Introducción de los métodos cualitativos de investigación. Buenos Aires: Paidós.

Ulin, P., Robinson, E., \& Tolley, E. (2006). Investigación aplicada en salud pública. Métodos cualitativos. Washington, DC: Organización Panamericana de la Salud.

UNICEF. (2005) Early marriage: A harmful traditional practice. New York: UNICEF.

World Health Organization. (2007) International Statistical Classification of Diseases and Related Health Problems, 10th Revision (WHO.ICD 10). Version for 2007. Geneva: WHO. 